\title{
Ice dynamics during a surge of Sortebræ, East Greenland
}

\author{
Tavi Murray, ${ }^{1}$ Tazio Strozzi, ${ }^{2,3}$ Adrian Lugkman, ${ }^{3}$ Hamish Pritchard, ${ }^{1,3}$ Hester Jiskoot $^{1}$ \\ ${ }^{1}$ School of Geography, University of Leeds, Leeds LS2 97T, England \\ ${ }^{2}$ Gamma Remote Sensing, Thunstrasse 130, CH-3074 Bern, Switzerland \\ ${ }^{3}$ Department of Geography, University of Wales, Swansea, Singleton Park, Swansea SA2 8PP, Wales
}

\begin{abstract}
Sortebræ, a large tidewater-terminating glacier in East Greenland, underwent a major surge between 1992 and 1995 during which the glacier terminus advanced by nearly $10 \mathrm{~km}$. In this paper, intensity tracking, interferometry and visual interpretation have been used to characterize the ice dynamics during the surge from satellite synthetic aperture radar images. The surge had a rapid initiation that saw velocities increase by $60-1500$ times, and within 13 months the entire lower $53 \mathrm{~km}$ of the glacier was affected. Surge termination occurred very rapidly during summer, and ice velocity dropped from around $20 \mathrm{~m} \mathrm{~d}^{-1}$ to around $2 \mathrm{~m} \mathrm{~d}^{-1}$ in only 3 months. Uniquely, part of the upper glacier remained fast-flowing even after the main surge event had terminated. Ice dynamics together with observations of large turbid lakes at the glacier margins suggest that the surge resulted from a throttling of basal water by a switch in the hydrological system.
\end{abstract}

\section{INTRODUCTION}

Surge-type glaciers switch between long periods of slow flow and short periods of accelerated flow, 10-1000 times faster. This type of glacier is relatively unusual and constitutes only around 1\% of all glaciers on Earth (Jiskoot and others, 1998). However, surge-type glaciers have been intensively studied because different basal processes are thought to govern the two distinct modes of flow between which these glaciers are able to switch. Such switching is not limited to surge-type glaciers: ice streams, which regulate the volume of the major ice sheets, can also switch their flow mode (Clarke, 1987), and thus surge-type glaciers may provide a useful analogue for ice-stream behaviour.

Surge-type glaciers are not uniformly distributed within the Earth's glaciated regions, being completely absent from some regions but clustered in other regions. There are striking differences in surge behaviour between cluster regions; in Svalbard, for instance, glaciers have both a long quiescent and a long active phase compared to other clusters (Dowdeswell and others, 1991). Central East Greenland is a cluster region in which 26 glaciers exhibit morphological evidence of surging (Weidick, 1988). In this cluster, observations are sparse and exist for only four active-phase glaciers (Rutishauser, 1971; Colvill, 1984; Weidick, 1988). These observations suggest a surge duration of 5-10 years and a quiescent-phase duration of 70-150 years. In this paper we use intensity tracking, interferometry and visual interpretation of satellite synthetic aperture radar (SAR) imagery to document the distribution and temporal evolution of ice dynamics of Sortebræ, central East Greenland, during its 1990s surge.

\section{LOGATION AND GHARACTERISTICS OF SORTEBRÆ}

Sortebræ $\left(68^{\circ} 45^{\prime} \mathrm{N}, 27^{\circ} 05^{\prime} \mathrm{W}\right)$ is a $65 \mathrm{~km}$ long tidewater- terminating glacier in central East Greenland (Fig. 1). The glacier is fed from a number of tributaries and by ice flowing from an ice cap on the Geikie Plateau. A major tributary, Sortebræ West, joins Sortebræ close to the ice terminus. Sortebræ West has an independent flow regime and is probably a continuously fast-flowing glacier, with ice velocities of 1.0-2.7 $\mathrm{m} \mathrm{d}^{-1}$ measured in both the 1930s and 1990s (Jiskoot and others, in press). Sortebræ surged around 1950 and again between 1992 and 1995, giving a quiescent phase of 39-49 years. Based on interpretation of aerial photographs, Jiskoot and others (in press) estimate the quiescent-phase velocity at the junction between Sortebræ and Lower Loop Basin to be $0.5 \pm 0.1 \mathrm{~m} \mathrm{~d}^{-1}$ over the period $1933-43$ and $0.02 \pm 0.007 \mathrm{~m} \mathrm{~d}^{-1}$ during 1981-87. During the 1990s surge, Sortebræ advanced $5 \mathrm{~km}$ in $<1$ year, and ice-flow rates increased dramatically. Large turbid lakes appeared in the shear margins, suggesting very high basal water pressures, in excess of flotation pressures, and an inefficient water- evacuation system. Iceberg calving increased greatly at the terminus, with $\sim 12 \mathrm{~km}^{3}$ of ice being calved, and an area of approximately $335 \mathrm{~km}^{2}$ of the glacier surface became intensely crevassed (Jiskoot and others, in press).

Sortebræ overlies Tertiary basalts that are colomnary jointed and have a friable and porous vesicular zone (Pedersen and others, 1997). These rocks are readily eroded and the glacier surface is heavily mantled by moraine debris. During the 1990s surge, copious amounts of sediment appeared in marginal shear zones and turbid lakes. Furthermore, Sortebræ terminates in a fjord, which suggests the presence of marine clays underlying its lower reaches. Thus it is probable that the glacier overlies a soft sedimentary bed. The thermal regime of the glacier is unknown; the closest glaciers with known thermal regime are in the Stauninger Alps and are polythermal (Kirchner, 1963; Davis and others, 1973).

Topographic changes during Sortebræ's 1990s surge have been measured using multi-model photogrammetry (Jiskoot 


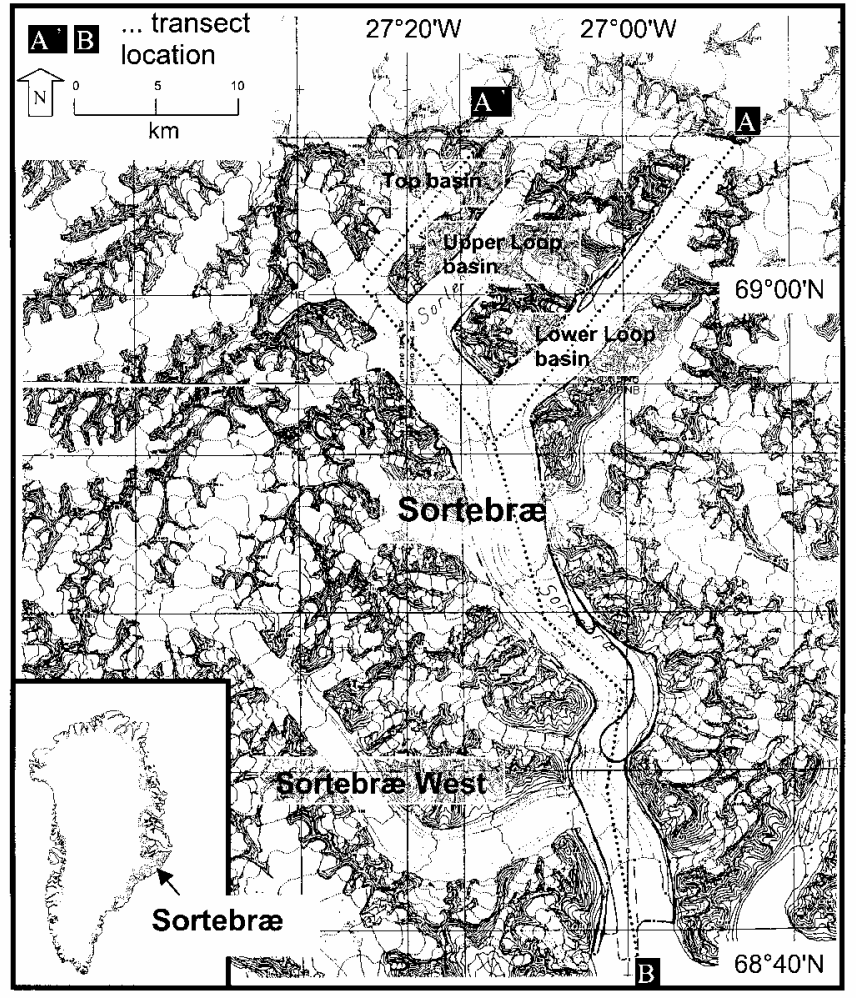

Fig. 1. Location of Sortebre, based on 1:100 000 topographic maps compiled by the Geological Survey of Denmark and Greenland from 1981 aerial photography and ground-control points supplied by the Danish National Survey and Cadastre. All names other than Sortebre are unofficial (Fiskoot and others, in press). The location of the profiles used in Figure 5 is shown. Contour interval is $100 \mathrm{~m}$.

and others, in press). Ice thinning in the reservoir zone varied spatially between 11 and $219 \mathrm{~m}$, and the thickening of the receiving zone varied between 24 and $74 \mathrm{~m}$.

\section{METHODS}

European Remote-sensing Satellite (ERS) SAR data covering Sortebræ suitable for interferometry and intensity tracking are only available after 21 April 1995 during the ERS-1/-2 tandem phase, since neither of the 3 day repeat phases of ERS-1 imaged this area. For this reason, annual non-paired SAR images were chosen at dates in late summer over the period 1992-97 to allow visual tracking of major features. Images for interferometry and intensity tracking were chosen from the tandem archive in conjunction with meteorological data from Danish Meteorological Institute stations at Aputiteeq and Scoresby Sund to ensure that only data with minimal loss of coherence due to melt, precipitation or drifting snow were chosen. Suitable image pairs were obtained from dates in May 1995, September 1995 and January 1996.

Interferograms were derived in the normal way (e.g. Goldstein and others, 1993) and the flat-Earth phase trend was removed using a combination of orbital information and Fourier-transform analysis of fringes. For the purposes of this paper neither differential processing nor unwrapping was performed, and the interferograms displayed contain both topographic and displacement information. Before
Table 1. Ice displacements during the surge based on displacement of a prominent moraine loop and the midpoint of the glacier margin (Fig. 2)

\begin{tabular}{lcc}
\hline Date & $\begin{array}{c}\text { Displacement of moraine loop } \\
\mathrm{m} \mathrm{d}^{-1}\end{array}$ & $\begin{array}{c}\text { Front movement } \\
\mathrm{m} \mathrm{d}^{-1}\end{array}$ \\
\hline $1992 / 93$ & 15.3 & 9.1 \\
$1993 / 94$ & 28.7 & 18.0 \\
$1994 / 95$ & 8.2 & -1.5 \\
$1995 / 96$ & 1.2 & -1.2 \\
$1996 / 97$ & 0.4 & -1.0 \\
\hline
\end{tabular}

Notes: Displacements are estimated to be accurate to \pm one pixel, and hence displacement rates are estimated to be accurate to $\pm 0.07 \mathrm{md}^{-1}$.

display, interferograms were geocorrected to the ellipsoid but not for topography.

The extreme velocities during many surges mean that SAR interferometry is unsuitable for mapping ice dynamics. For example, Fatland and Lingle (1998) used interferometry to study the effects of Bering Glacier, Alaska, U.S.A., on the Bagley icefield that feeds it, but ice velocities were so high on the glacier itself that coherence was lost. Similarly, studies on Storstrømmen, North Greenland, used interferometry only in the quiescent phase of its surge (Mohr and others, 1998). However, tracking nearly identical intensity features at the scale of groups of pixels between two SAR images allows assessment of surface displacements where relatively large displacements have occurred (Rott and others, 1998; Michel and Rignot, 1999; Werner and others, 2001). This method thus provides the possibility for mapping rapid ice displacement during the active phase of surging.

Automatic cross-correlation of image patches of detected real-valued SAR intensity images was performed in slantrange and azimuth directions (Werner and others, 2001). Image patches were $64 \times 64$ single look complex (SLG) pixels, i.e. around $500 \mathrm{~m}$ in the slant-range direction and $250 \mathrm{~m}$ in the azimuth direction, which limits the resolution of the technique. It should be noted that because of the differing pixel size the technique is less sensitive in the slant-range than in the azimuth direction. The confidence level of each offset was estimated to remove unreliable data. The detected pixel shifts were corrected for orbit offsets to derive an absolute, unambiguous motion of the glacier. Offsets were corrected to horizontal for the look-angle of the satellite, and images were geocoded to the ellipsoid before display. Assuming range- and azimuth-offset estimation errors of 0.05 pixel (Werner and others, 2001), the displacement estimation errors for ERS SAR offset-tracking are $\sim 0.4 \mathrm{~m}$ in slant-range $($ or $\sim 1.0 \mathrm{~m}$ in ground-range) and $\sim 0.2 \mathrm{~m}$ in azimuth directions. The accuracy depends on the direction of motion, but generally the technique is only suitable for measuring fast displacements of $>1 \mathrm{~m}$ between image acquisitions.

\section{RESULTS}

\section{Interpretation of SAR images}

Figure 2 shows the lower $25 \mathrm{~km}$ of Sortebræ taken from annual SAR images which allow tracking of major moraine features and measurement of the frontal advance and retreat (Table 1). The images were chosen from the archive to 


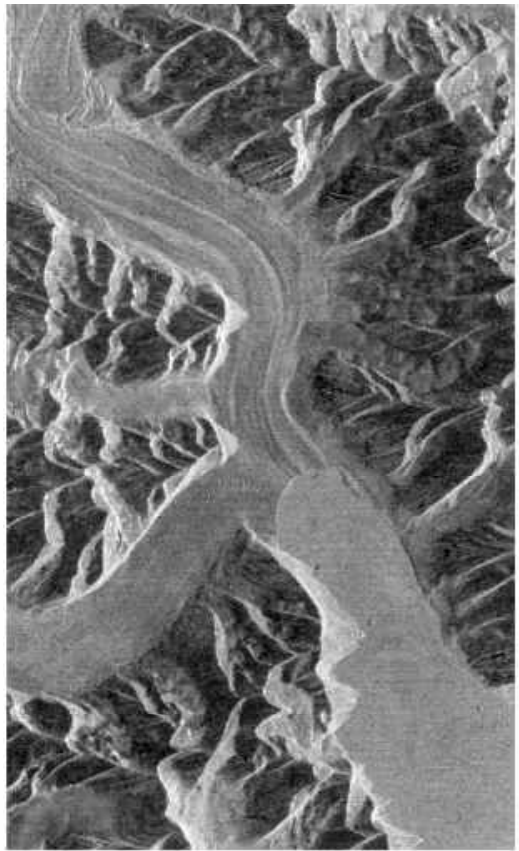

(a) 30-09-1992

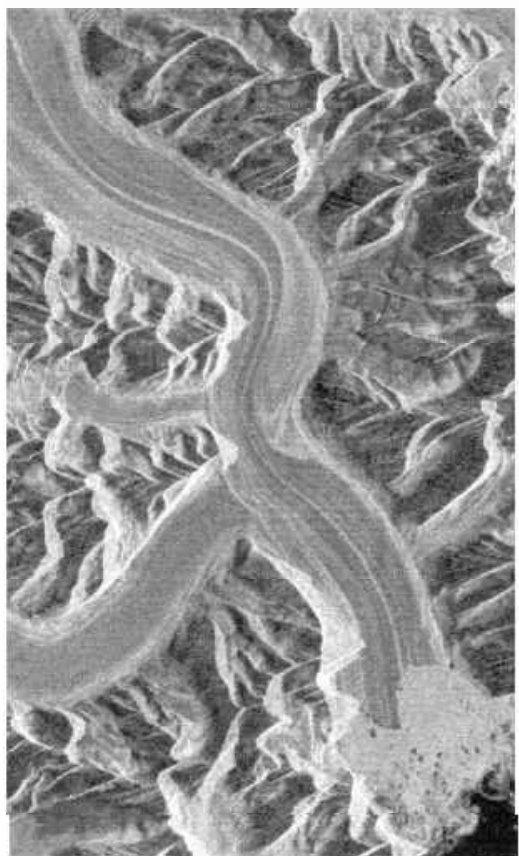

(d) 09-09-1995

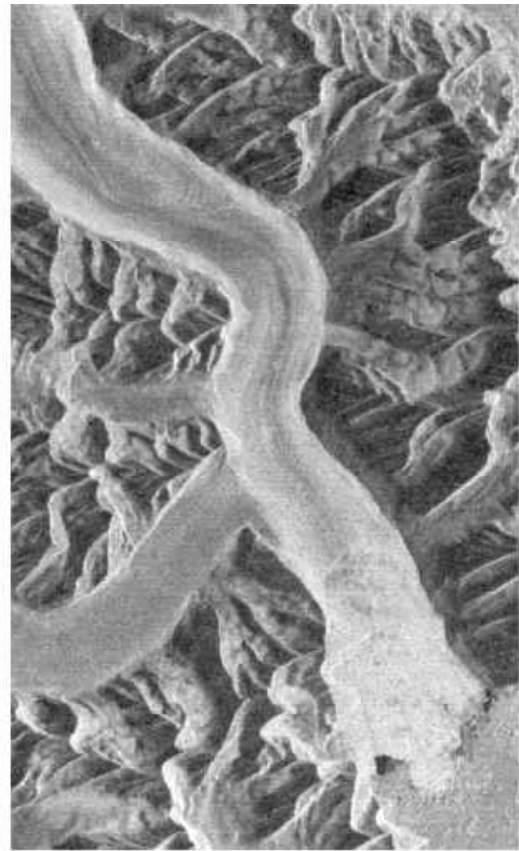

(b) 20-10-1993

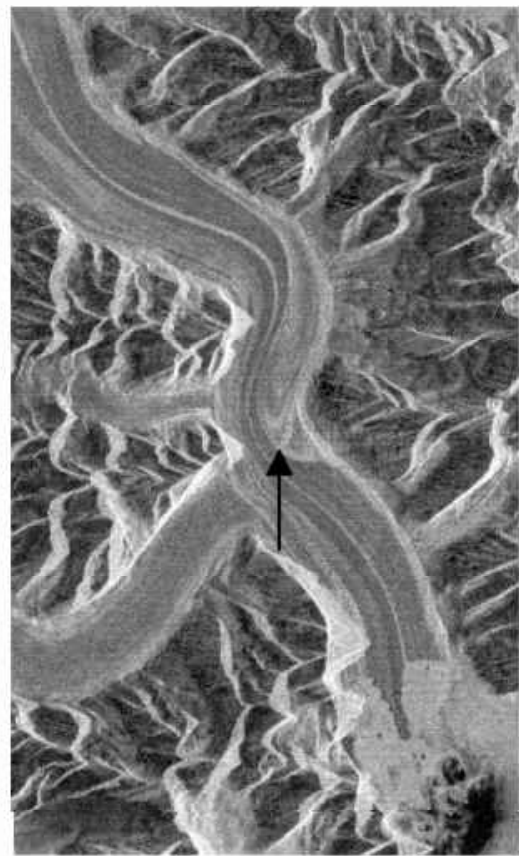

(e) 24-08-1996

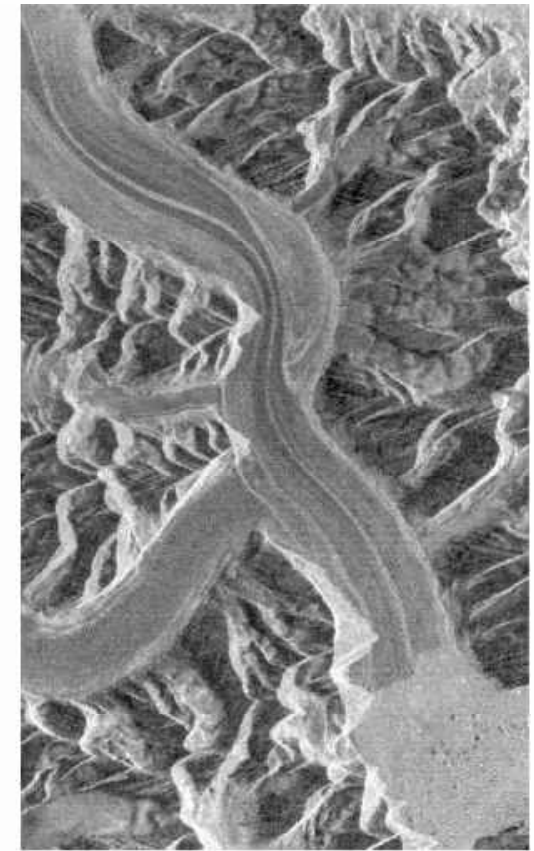

(c) 19-09-1994

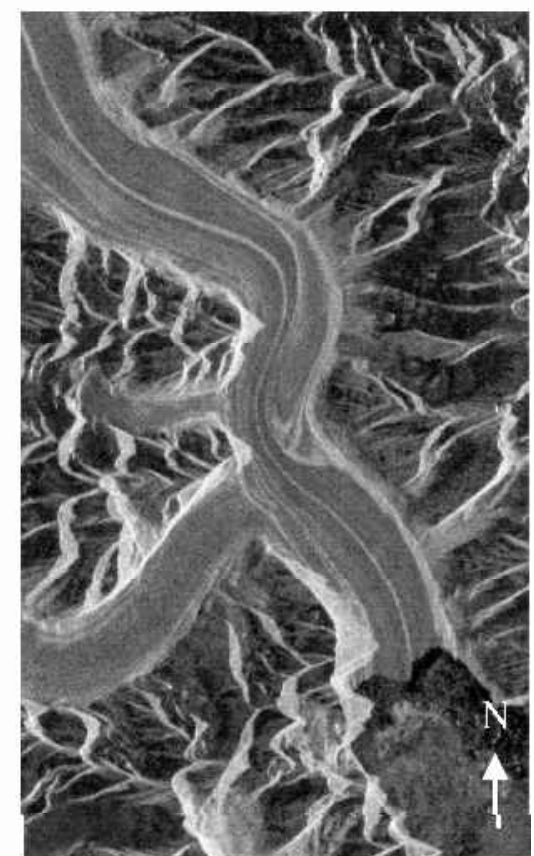

(f) 05-07-1997

Fig. 2. Sequence of SAR images of the marginal region of the glacier at approximately 1 year intervals through the surge cycle. Note the increase in the surface brightness of the glacier during 1993, presumably caused by intense crevassing. The marginal advance and retreat, and the displacement of the moraine loop (from the top to the centre of these images) can also be seen. Images are $18 \mathrm{~km} \times 30 \mathrm{~km}$. Look direction is from the right (east-southeast).

represent as closely as possible the same seasonal conditions in each year, and were calibrated to be directly intercomparable in brightness. Any residual overall brightness differences will result from differing local conditions between the acquisitions chosen (e.g. changes in snow water content or surface roughness). These images show that Sortebræ's surge started after 30 September 1992 and before 20 October 1993. In 1992, Sortebræ West dominated the calving front, and the surface of Sortebræ was pitted and depleted, with many moraines standing proud of the ice surface (Fig. 2a). There was no evidence of a surge front, but by October 1993 (Fig. 2b) the entire lower $53 \mathrm{~km}$ of glacier surface was very bright in contrast to neighbouring glaciers, making moraines and other features indistinct, probably due to the formation of many crevasses that produced strong radar backscatter. The glacier terminus was not easily distinguishable due to extensive calf and brash ice in the fjord. The surging trunk of Sortebræ appeared to shear off Sortebræ West and most small tributaries, but the Lower Loop, Upper Loop and Top basins (Fig. 1) were all affected by the surge. Between 1992 and 1993, the centre of the glacier terminus advanced about $3.5 \mathrm{~km}$ at a rate of at least $9.1 \mathrm{~m} \mathrm{~d}^{-1}$, and displacement of the moraine loop suggests ice-displacement rates of at least $15.3 \mathrm{~m} \mathrm{~d}^{-1}$ during the same period. Both frontal advance and ice-displacement rates could be much higher if in fact the surge started closer to the 1993 rather than the 1992 image. (A SAR image from 10 July 


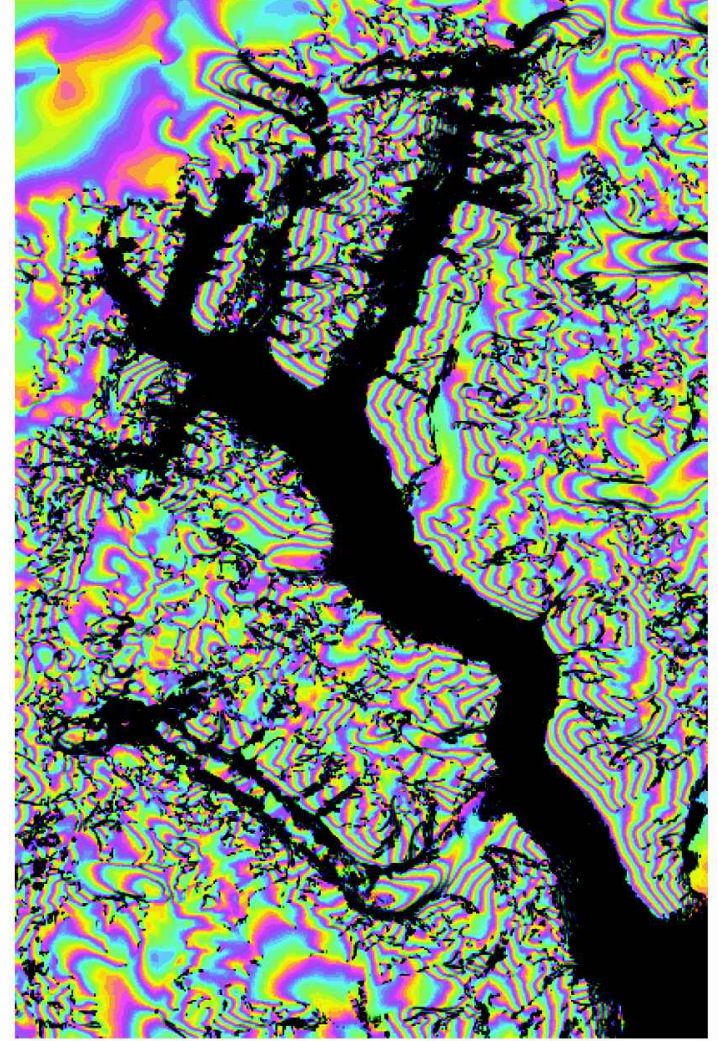

(a) 26 and 27 May 1995

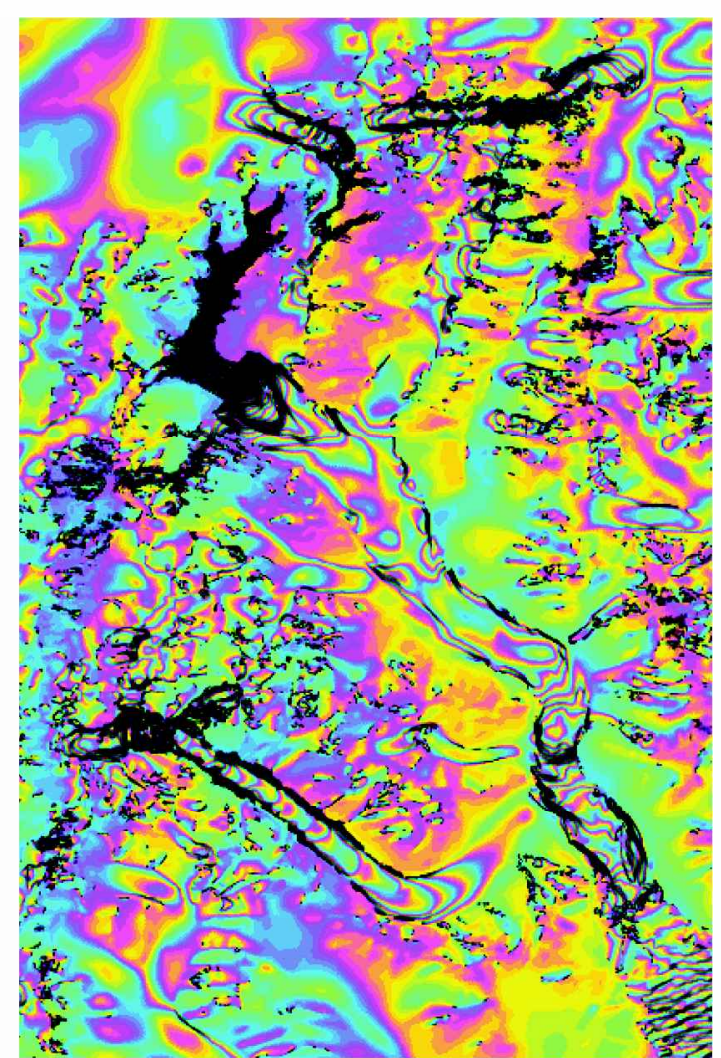

(b) 7 and 8 January 1996

Fig. 3. Flattened interferograms of Sortebre for (a) May 1995 and (b) Fanuary 1996. The images show both topography and displacement effects on the phase and are combined with the backscatter intensity and the coherence. The entire main trunk is incoherent in (a) due to very high ice-displacement rates, whereas most of the main trunk is coherent in (b). Image is $40 \mathrm{~km} \times 60 \mathrm{~km}$. Perpendicular component of the baseline for $(a)$ is $-47 \mathrm{~m}$ and for $(b)$ is $-11 \mathrm{~m}$. Look direction is from the right (east-southeast).

1993 obtained after this paper was written shows only minor displacement of the moraine loop and terminus between September 1992 and July 1993 and thus suggests that the surge started shortly before July 1993.)
Maximum annual frontal advance occurred between 1993 and 1994, when the terminus advanced $\sim 6.0 \mathrm{~km}$ at a rate of $\sim 18 \mathrm{~m} \mathrm{~d}^{-1}$ (Table 1). Over this period the moraine loop in the centre of the image was displaced at rates of

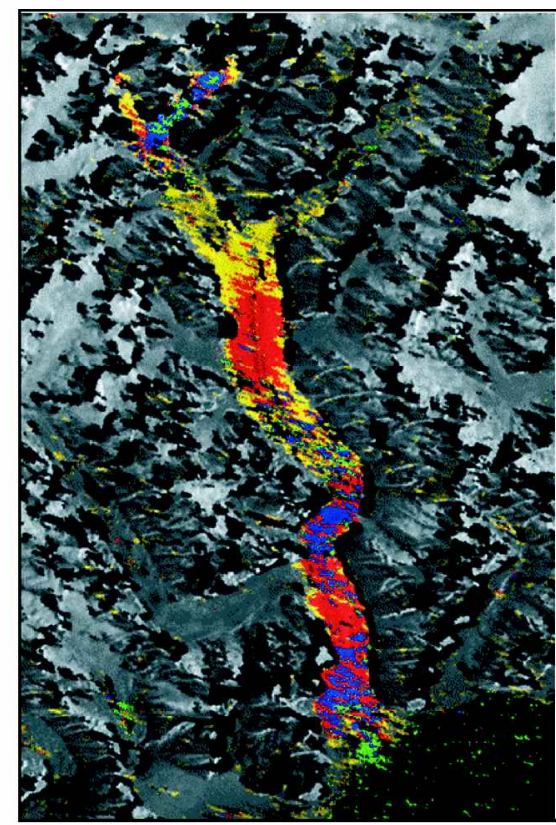

(a) 26 and 27 May 1995

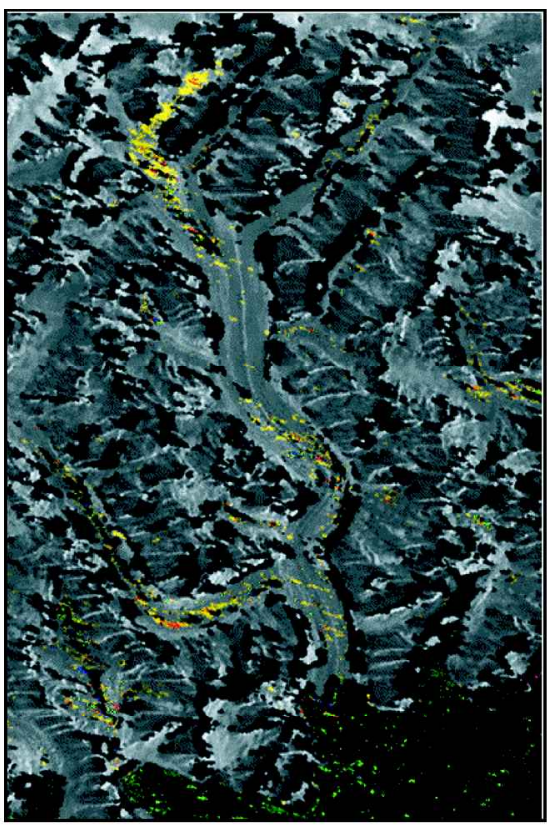

(b) 8 and 9 September 1995

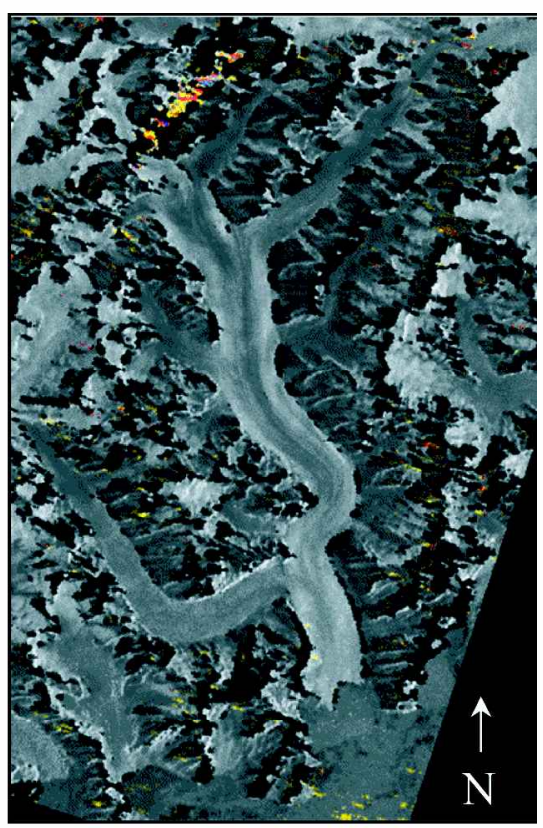

(c) 7 and 8 January 1996

Fig. 4. Horizontal displacement from intensity tracking. Green: $>20 \mathrm{md}^{-1}$; blue: $15-20 \mathrm{md}^{-1}$; red 10-15 $\mathrm{m}^{-1}$; yellow: 5-10 $\mathrm{md}^{-1}$; backscattering intensity image <5m $d^{-1}$; black: no data. (a) May 1995; (b) September 1995; (c) January 1996. Image is $40 \mathrm{~km} \times 60 \mathrm{~km}$. 


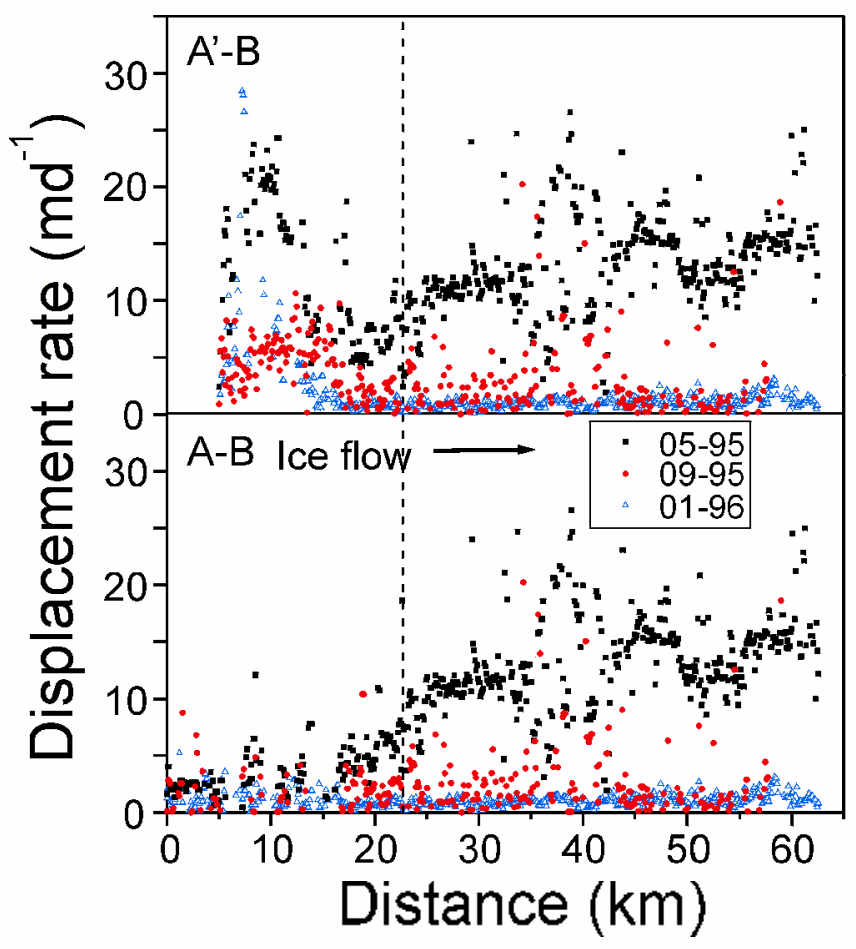

Fig. 5. Horizontal displacement from intensity tracking from images 26 and 27 May 1995, 8 and 9 September 1995, and 7 and 8 January 1996. Accuracy of intensity tracking is $\pm 1.2 \mathrm{md}^{1}$. Location of profiles is shown in Figure 1; profiles are identical after $23 \mathrm{~km}$ (to the right of dashed line). Measured small-scale velocity variability appears to be at or greater than the expected error in the tracking technique, possibly because of true small-scale changes in surface flow, for example related to crevassing.

$\sim 29 \mathrm{~m} \mathrm{~d}^{-1}$. After this time the glacier started to retreat slowly as ice velocities fell, presumably becoming too low to replenish the ice being lost to calving. The total advance of the glacier front was 7-10 km over 2-3 years, after which the glacier front retreated irregularly (Fig. 2c-f). From these images it appears that the surge terminated before 9 September 1995.

Moraine displacements and surface expression near the confluence of the Lower Loop basin suggest that the surge started in this tributary and propagated both up- and downglacier in the main trunk. This observation is in accordance with a preliminary study of crevasse patterns on the glacier and the pattern of glacier thinning and thickening, which both suggest an initiation about halfway up the Lower Loop basin (Jiskoot and others, in press).

\section{Interferometry}

An interferogram formed from images from 26 and 27 May 1995 showed no coherence over Sortebræ, despite good coherence on neighbouring glaciers including most of Sortebræ West (Fig. 3a). This result implies decorrelation over Sortebræ due to rapid flow. However, the September 1995 interferogram showed some coherence over part of Sortebræ, and by January 1996 (Fig. 3b) most of Sortebræ was coherent, suggesting that the ice-flow rate had fallen dramatically and that the surge had terminated. Ice in the Top basin remained fast-flowing through September 1995 and January 1996, and the margin of fast-moving ice migrated slowly up-glacier.

\section{Intensity tracking}

Intensity tracking successfully allowed determination of ice velocity over most of the glacier (Fig. 4). Profiles along flowlines are displayed in Figure 5. Tracking shows clearly the dramatic drop in velocity between May and September 1995 over most of the glacier. In May, the velocity in the main trunk was $\sim 13 \mathrm{~m} \mathrm{~d}^{-1}$ and generally increased downglacier showing overall extensional flow. There were largescale variations in velocity related to the glacier's flow around bends (Fig. 1). In May 1995, the velocity was lowest in the Lower Loop basin (Fig. 5), which is the site inferred to be the surge nucleus region (Jiskoot and others, in press). By September, the velocity in the main trunk had dropped to $1-3 \mathrm{~m} \mathrm{~d}^{-1}$ and in January 1996 it was $\sim 1 \mathrm{~m} \mathrm{~d}^{-1}$. In the Top basin, intensity tracking showed velocities of $15-25 \mathrm{~m} \mathrm{~d}^{-1}$ during May 1995 (Fig. 5), and by September 1995 the velocity in this region had dropped to $\sim 5 \mathrm{~m} \mathrm{~d}^{-1}$. In January 1996, the velocity appears to have increased again in some parts of the Top basin, although typical velocities were still $\sim 5 \mathrm{~m} \mathrm{~d}^{-1}$. Maximum velocities in January 1996 in the Top basin were $25-30 \mathrm{~m} \mathrm{~d}^{-1}$, and the region of fastest flow in this region had moved up-glacier compared to the full surge conditions of May 1995.

\section{DISGUSSION}

Based on the interpretation of SAR images (Fig. 2) and interferograms (Fig. 3), Sortebræ's surge initiated after September 1992 and before October 1993, and ended after May and before September 1995. The surge was therefore 19-35 months in duration. The glacier front began advancing very soon after the surge initiated (Table 1), and the whole glacier was rapidly activated. Based on the evidence presented in this paper we cannot determine the season of surge initiation, which is unfortunate, given the prediction that the closure of the conduit system required for the production of linked cavities will occur in winter (Raymond, 1987). Surge termination occurred during summer. There is no visual evidence of a surge front on any of the images (Fig. 2), so if a surge front propagated down-glacier it did so within at most the first 13 months of the surge.

Observations of glacier surging reveal two distinct classes of glacier surges. The first class is typified by the well-documented Variegated Glacier, Alaska (e.g. Kamb and others, 1985; Kamb, 1987). This surge was characterized by rapid onset and cessation of fast flow and very high ice-flow velocities and has been explained as resulting from a hydrological instability (Kamb, 1987). During quiescence, the glacier basal water system is thought to be channelized, allowing efficient and rapid water evacuation. During the surge phase, the water becomes throttled in linked cavities, which allow storage of a large volume of water at high water pressures, thus facilitating fast flow. This is essentially a hard-bed surge mechanism, although Kamb (1987) states that the linkedcavity model is "applicable in a general way to surging when soft bed deformation contributes to the high speeds of ice motion", and observations at Skeiðarárjökull, Iceland, support this (Bjørnsson, 1998). The second class is typified by Svalbard glaciers (e.g. Dowdeswell and others, 1991). In Svalbard, surges are of longer duration ( $>5$ years), and are typified by low ice velocities, low basal shear stresses and slow and indistinct initiations (personal communication from A.-M. Nuttall, 1999) and terminations (Murray and others, 


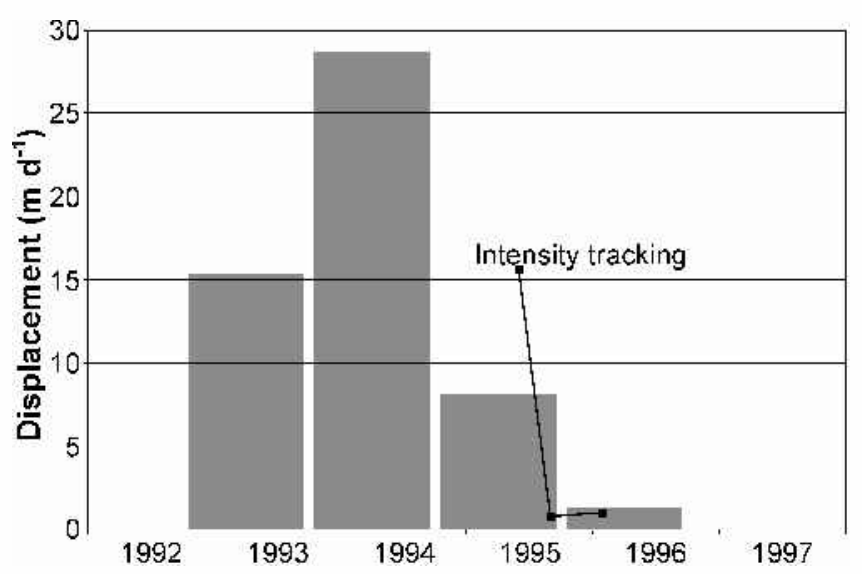

Fig. 6. Ice displacement at Sortebre from a combination of visual tracking of moraine features (bars) and intensity tracking (points) at location of moraine loop (Fig. 1).Visual tracking provides annual averages, whereas intensity tracking provides instantaneous point values. The rapid surge termination can clearly be seen.

1998). These surges have been shown to be related to soft beds and polythermal regimes (Jiskoot and others, 2000; Murray and others, 2000). Reports of surges in East Greenland would suggest that glaciers in this cluster resemble Svalbard rather than Alaskan glaciers (e.g. Weidick, 1988).

At Sortebræ the rapid surge initiation and termination (Fig. 6) is in contrast to observations in the Svalbard archipelago (e.g. Dowdeswell and others, 1991; Murray and others, 1998) but is similar to glaciers in Alaska and other regions (Kamb and others, 1985; Harrison and others, 1994). Ice velocities at Sortebræ are much higher than those reported in Svalbard, which are typically $6 \mathrm{~m} \mathrm{~d}^{-1}$ or less (e.g. Rolstad and others, 1997; Dowdeswell and others, 1998; Murray and others, 1998). However, velocities at Sortebræ are somewhat lower than those of Alaskan glaciers (Harrison, 1964; Kamb and others, 1985; Echelmeyer and others, 1987; Harrison and others, 1994) or Medvezhy glacier in the Pamirs (Dolgoushin and Osipova, 1975), where maximum surge velocities are $50-100 \mathrm{~m} \mathrm{~d}^{-1}$ or more. Despite the apparently intermediate velocities we have measured, the combination of field observations of very high basal water pressures, which trapped sufficient volume of water to fill marginal lakes with turbid water, and the rapid onset and termination, imply surge propagation by a mechanism similar to that of Variegated Glacier, i.e. a hydrological switching mechanism. However, it is highly likely that Sortebræ overlies a soft and potentially deformable bed, which may prove to be a cause of the intermediate surge velocities.

Surge termination occurred rapidly over most of the glacier (Figs 3, 4 and 6), but the Top basin of Sortebræ remained fast-flowing at velocities of $5-25 \mathrm{~m} \mathrm{~d}^{-1}$ or more (Figs 4 and 5), and the boundary of this fast flow propagated slowly up-glacier. Flow in this region is inevitably strongly compressive in the region of decreasing velocity (Fig. 5). Water must be trapped beneath this region of the glacier and prevented from escaping. The stability of linked cavities is promoted by low slope, high basal shear stress (i.e. thick ice) and high sliding velocity (Kamb, 1987). Since this region of the glacier had little obvious surface expression either before or after the surge, it is unlikely that ice surface slope played a major role in maintaining a stable highwater-pressure system. Basal topography, i.e. the presence of an overdeepening, increasing ice depth and hence basal shear stress, may have played an important role in retaining water in this region of the glacier.

\section{SUMMARY AND GONGLUSIONS}

Sortebræ has a surge phase of 19-35 months and a quiescent phase of 39-49years. Ice flow during the surge increased by up to 60-1500 times over quiescent-phase velocities and was sustained at rates of up to $30 \mathrm{~m} \mathrm{~d}^{-1}$ over a year.

Glacier surge initiation was rapid, and after a period of at most 13 months the lower $53 \mathrm{~km}$ of the glacier was affected, showing widespread crevassing and greatly increased calving.

Intensity tracking successfully allowed velocity determination over most of the glacier. This tracking showed that surge termination was rapid, with velocities dropping over most of the glacier from approximately $10-20 \mathrm{~m} \mathrm{~d}^{-1}$ to approximately $1-2 \mathrm{~m} \mathrm{~d}^{-1}$ over 3 months.

The season of surge initiation is unknown, but surge termination occurred during summer 1995.

Ice velocities in the Top basin remained high $\left(5-30 \mathrm{~m} \mathrm{~d}^{-1}\right)$ well after the surge terminated in the remainder of the glacier.

Surge glacier dynamics at Sortebræ appear similar to those at Variegated Glacier, Alaska. At Sortebræ, the basal water system appears to have been characterized by very high water pressures and storage of large volumes of water during the surge. Surge propagation is thought to result from a hydrological instability. However, it is highly likely that Sortebræ overlies a soft and deformable substrate.

\section{AGKNOWLEDGEMENTS}

This study was funded through grants from the Royal Society and the U.K. Natural Environment Research Council (NERG). T.S. and H.J. are supported by the NERG grant GST/02/2192, and H.P. is funded through NERG Ph.D. Studentship GT4/99/120.

\section{REFERENGES}

Björnsson, H. 1998. Hydrological characteristics of the drainage system beneath a surging glacier. Nature, 395(6704), 771-774.

Clarke, G. K. C. 1987. Fast glacier flow: ice streams, surging and tidewater glaciers. F. Geophys. Res., 92(B9), 8835-8841.

Colvill, A. J. 1984. Some observations on glacier surges, with notes on the Roslin glacier, East Greenland. In Miller, K.J., ed. The International Karakoram Project. Proceedings of the International Conference. Vol. 1. Cambridge, Cambridge University Press, 64-75.

Davis, J. L., J. S. Halliday and K. J. Miller. 1973. Radio echo sounding on a valley glacier in East Greenland. F. Glaciol., 12(64), 87-91.

Dolgoushin, L. D. and G. B. Osipova. 1975. Glacier surges and the problem of their forecasting. International Association of Hydrological Sciences Publication 104 (Symposium at Moscow 1971 - Snow and Ice ), 292-304.

Dowdeswell, J.A., G. S. Hamilton and J. O. Hagen. 1991. The duration of the active phase on surge-type glaciers: contrasts between Svalbard and other regions. 7. Glaciol., 37(127), 388-400.

Dowdeswell, J. A., B. Unwin, A.-M. Nuttall and D. J.Wingham. 1998. Velocity structure, flow instability and mass flux on a large Arctic ice cap from 
satellite radar interferometry. Earth Planet. Sci. Lett., 167(3-4), 131-140.

Echelmeyer, K., R. Butterfield and D. Cuillard. 1987. Some observations on a recent surge of Peters Glacier, Alaska, U.S.A. F. Glaciol., 33(115), 341-345.

Fatland, D. R. and C. S. Lingle. 1998. Analysis of the 1993-95 Bering Glacier (Alaska) surge using differential SAR interferometry. F. Glaciol., 44(148), 532-546.

Goldstein, R. M., H. Engelhardt, B. Kamb and R. M. Frolich. 1993. Satellite radar interferometry for monitoring ice sheet motion: application to an Antarctic ice stream. Science, 262(5139), 1525-1530.

Harrison, A. E. 1964. Ice surges on the Muldrow Glacier, Alaska. F. Glaciol., $\mathbf{5}(39), 365-368$.

Harrison, W. D., K. A. Echelmeyer, E. F. Chacho, C. F. Raymond and R. J. Benedict. 1994. The 1987-88 surge of West Fork Glacier, Susitna Basin, Alaska, U.S.A. 7. Glaciol., 40(135), 241-254.

Jiskoot, H., P. Boyle and T. Murray. 1998. The incidence of glacier surging in Svalbard: evidence from multivariate statistics. Comput. Geosci., 24(4), 387-399.

Jiskoot, H., T. Murray and P. Boyle. 2000. Controls on the distribution of surge-type glaciers in Svalbard. F. Glaciol., 46(154), 412-422.

Jiskoot, H., A. K. Pedersen and T. Murray. In press. Multi-model photogrammetric analysis of the 1990s surge of Sortebræ, East Greenland. F. Glaciol.

Kamb, B. 1987. Glacier surge mechanism based on linked cavity configuration of the basal water conduit system. F. Geophys. Res., 92(B9), 9083-9100.

Kamb, B. and 7 others. 1985. Glacier surge mechanism: 1982-1983 surge of Variegated Glacier, Alaska. Science, 227(4686), 469-479.

Kirchner, G. 1963. Observations at bore holes sunk through the Schuchert Gletscher in north-east Greenland. f. Glaciol., 4(36), 817-818.

Michel, R. and E. Rignot. 1999. Flow of Glaciar Moreno, Argentina, from repeat-pass Shuttle Imaging Radar images: comparison of the phase correlation method with radar interferometry. F. Glaciol., 45(149), 93-100.

Mohr, J.J., N. Reeh and S. N. Madsen. 1998. Three-dimensional glacial flow and surface elevation measured with radar interferometry. Nature, 391 (6664), 273-276.

Murray, T., J. A. Dowdeswell, D. J. Drewry and I. Frearson. 1998. Geometric evolution and ice dynamics during a surge of Bakaninbreen, Svalbard. 7 . Glaciol., 44(147), 263-272. (Erratum: 45(150), 1999, p. 405.)

Murray, T. and 6 others. 2000. Glacier surge propagation by thermal evolution at the bed. 7. Geophys. Res., 105(B6), 13,491-13,507.

Pedersen, A. K., M. Watt, W. S. Watt and L. M. Larsen. 1997. Structure and stratigraphy of the Early Tertiary basalts of the Blosseville Kyst, East Greenland. F. Geol. Soc. London, 154(3), 565-570.

Raymond, C. F. 1987. How do glaciers surge? A review. 7. Geophys. Res., 92(B9), 9121-9134.

Rolstad, C., J. Amlien, J. O. Hagen and B. Lundén. 1997. Visible and nearinfrared digital images for determination of ice velocities and surface elevation during a surge on Osbornebreen, a tidewater glacier in Svalbard. Ann. Glaciol., 24, 255-261.

Rott, H., M. Stuefer, A. Siegel, P. Skvarca and A. Eckstaller. 1998. Mass fluxes and dynamics of Moreno Glacier, Southern Patagonia Icefield. Geophys. Res. Lett., 25(9), 1407-1410.

Rutishauser, H. 1971. Observations on a surging glacier in East Greenland. 7. Glaciol., 10 (58), 227-236.

Weidick, A. 1988. Surging glaciers in Greenland: a status. Grønl. Geol. Undersøgelse, Rapp. 140, 106-110.

Werner, C. and 6 others. 2001. Complimentary measurement of geophysical deformation using repeat-pass SAR. In IGARSS 2001. 21st International Geoscience and Remote Sensing Symposium, 9-13 July 2001, Sydney, Australia. Proceedings. Piscataway, NJ, Institute of Electrical and Electronics Engineers, CD-ROM. 